TITLE:

\title{
Effect of glucosamine and related compounds on the degranulation of mast cells and ear swelling induced by dinitrofluorobenzene in mice.
}

\section{$\operatorname{AUTHOR(S):~}$}

Sakai, Shota; Sugawara, Tatsuya; Kishi, Toshihiro; Yanagimoto, Kenichi; Hirata, Takashi

\section{CITATION:}

Sakai, Shota ... [et al]. Effect of glucosamine and related compounds on the degranulation of mast cells and ear swelling induced by dinitrofluorobenzene in mice.. Life sciences 2010, 86(9-10): 337-343

ISSUE DATE:

2010-02-27

URL:

http://hdl.handle.net/2433/102279

\section{RIGHT:}

c 2010 Elsevier Inc.; This is not the published version. Please cite only the published version.; この論文は出版社版でありません。引用の際に は出版社版をご確認ご利用ください。 
1 Effect of glucosamine and related compounds on the degranulation of mast cells and ear

2 swelling induced by dinitrofluorobenzene in mice

3

4 Shota Sakai ${ }^{*}$, Tatsuya Sugawara ${ }^{*}$, Toshihiro Kishi $^{\dagger}$, Kenichi Yanagimoto ${ }^{\dagger}$ and Takashi 5 Hirata $^{*}$

6

$7 \quad$ *Division of Applied Biosciences, Graduate School of Agriculture, Kyoto University, Kyoto

8 606-8502, Japan; and †Human Life Science R\&D Center, Nippon Suisan Kaisha Ltd., Tokyo

9 100-8686, Japan

10

11 Corresponding Author: Tatsuya Sugawara

12 Division of Applied Biosciences, Graduate School of Agriculture, Kyoto University

13 Kyoto 606-8502, Japan.

14 E-mail: sugawara@kais.kyoto-u.ac.jp; Telephone: 81757536212

15 


\section{Abstract}

2 Aims: Glucosamine has been safely used to relieve osteoarthritis in humans, but the precise

3 mechanism underlying its efficacy is still unclear. In this study, we investigated the direct

4 effects of glucosamine and related compounds on mast cell mediated inflammation using

5 cultured mast cells and an animal model.

6 Main methods: Dinitrophenyl (DNP)-IgE sensitized rat basophilic leukemia RBL-2H3 cells

7 were treated with glucosamine- $\mathrm{HCl}$ (GlcN-HCl), $\mathrm{N}$-acetylglucosamine (GlcNAc), chitin

8 oligomer or chitosan oligomer. Cells were stimulated by DNP-BSA to induce degranulation

9 and released $\beta$-hexosaminedase was determined colorimetrically to measure the degree of

10 degranulation. Dinitrofluorobenzene (DNFB) sensitized BALB/c mice were administrated

11 orally with 1 or $0.1 \mathrm{mg} \mathrm{GlcN-HCl}$ or GlcNAc for 6 days. One h after the final administration,

12 mice was challenged by DNFB to induce ear swelling.

13 Key findings: GlcN-HCl significantly inhibited the antigen-induced degranulation of RBL-

$142 \mathrm{H} 3$ cells at higher than $0.01 \mathrm{mg} / \mathrm{mL}$ for $24 \mathrm{~h}$-treatment while GlcNAc, a chitin oligomer and

15 a chitosan oligomer had no effect. GlcN-HCl also suppressed intracellular calcium

16 mobilization. GlcN-HCl and GlcNAc significantly suppressed the antigen-induced up-

17 regulation of TNF- $\alpha$ and IL-6 mRNA. Ear swelling and histamine levels of plasma and ear in

18 DNFB-treated mice were significantly suppressed by oral administration of GlcN-HCl or

19 GlcNAc (0.1 and $1 \mathrm{mg})$ for 6 days.

20 Significance: Our results strongly suggest that GlcN-HCl and GlcNAc have anti-

21 inflammatory effects in vivo by suppressing the activation of mast cells.

22 Keywords: glucosamine; mast cells; degranulation; inflammation; osteoarthritis 


\section{Introduction}

Glucosamine, a naturally occurring amino-monosaccharide, is an essential component

3 of glycosaminoglycans in almost all human tissues, and glycosaminoglycans are highly

4 concentrated in connective and cartilage tissues (Laverty et al. 2005). Glucosamine and

5 related compounds, which are used as dietary supplements, appear to be safe and are widely

6 marketed for pain relief of osteoarthritis. In fact, numerous studies have shown that

7 glucosamine supplements provide symptomatic relief for osteoarthritis and can normalize

8 cartilage metabolism (Kim et al. 2005). However, clinical trials have yielded conflicting

9 results and the precise mechanism of the effects of glucosamine on arthritis is still obscure.

10 Recent studies raise questions about the positive effects of glucosamine sulfate on pain and

11 structural changes associated with osteoarthritis (Felson and Mcalindon 2000; Mcalindon et

12 al. 2004; Felson 2008). One speculative mechanism for the efficacy of glucosamine is its

13 direct effect on inflammatory reactions. There have been several reports about the potential immunoregulatory ability of glucosamine (Forchhammer et al. 2003; Meininger et al. 2000).

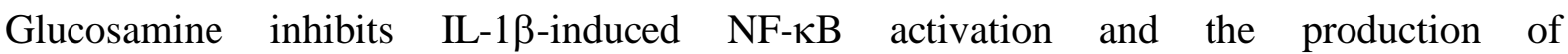
proinflammatory cytokines in human chondrocytes (Gouze et al. 2002; Shikhman et al. 2001), and suppresses the release of cytokines from $\mathrm{T}$ cells by disturbing the functions of antigen presenting cells (APCs) and by inhibiting CD3-induced $\mathrm{T}$ cell proliferation (Zhang et al. 2005).

Mast cells are commonly found at sites of contact with the outside environment and

21 they play pivotal roles in inflammation and immediate-type allergic reactions. Degranulation

22 of mast cells causes the secretion of biologically active substances including histamine,

23 eicosanoids, proteolytic enzymes, cytokines and chemokines. Cytokines released after

24 degranulation, such as interleukin-6 (IL-6), IL-8 and tumor necrosis factor-alpha (TNF- $\alpha$ ),

25 induce the late-phase allergic reactions and allergic inflammation via the recruitment of 
1 immune cells to the inflamed site (Feldmann et al. 1996). It is well known that the

2 degranulation of mast cells is induced by multivalent antigen-IgE crosslinking and the

3 aggregation of high affinity IgE receptor I (Kabu et al. 2006). The aggregation of high

4 affinity IgE receptor I triggers intracellular signaling pathways, such as the phosphorylation of

5 protein kinases and the influx of intracellular $\mathrm{Ca}^{2+}$. Based on this background, the assay for

6 degranulation of mast cells has been used for screening of anti-inflammatory natural 7 compounds.

8 Chitin is a polymer of $\mathrm{N}$-acetylglucosamine found abundantly in the exoskeleton of

9 crustaceans and insects and in the cell walls of fungi (Shibata et al. 2000; Georgopapadakou

10 and Tkacz 1995). Chitosan, a polymer of glucosamine, is obtained by the deacetylation of

11 chitin under alkaline conditions. N-acetylglucosamine and glucosamine are industrially

12 produced by the hydrolysis of chitin and chitosan. Glucosamine-related products, such as N-

13 acetylglucosamine, glucosamine, chitin and chitosan, have been used extensively to manage several biological functions. Especially, chitosan possesses many functional properties such as biodegradability, immunological and antibacterial activities, and wound-healing (Kuma et al. 2004) and is used in functional foods and drugs. However, there has been no report concerning the effect of glucosamine and related compounds on the degranulation of mast cells.

The objectives of this study were to investigate the anti-inflammatory activity of glucosamine and related compounds using cultured mast cells and an animal model, and to clarify the mechanism underlying its activity.

\section{Materials and methods}

$24 \quad$ Materials 
1 Glucosamine-HCl (GlcN-HCl), N-acetylglucosamine (GlcNAc), chitin oligomer (2-

27 mers of GlucNAc) and chitosan oligomer (less than 10mers of GlcN) were kindly provided

3 by Nippon Suisan Kaisha, Ltd. (Tokyo, Japan).

4

$5 \quad \beta$-Hexosaminidase release assay

6 Rat basophilic leukemia RBL-2H3 cells (Health Science Resources Bank, Osaka,

7 Japan) were cultured in RPMI-1640 medium containing 10\% FBS and supplemented

8 antibiotics (100 unit $/ \mathrm{mL}$ penicillin and $100 \mu \mathrm{g} / \mathrm{mL}$ streptomycin) at $37^{\circ} \mathrm{C}$ in humidified

9 atmosphere in the presence of $5 \% \mathrm{CO}_{2}$. The degree of degranulation of RBL-2H3 cells

stimulated by IgE-antigen was determined by the $\beta$-hexosaminidase release assay (Nakano et

11 al. 2005). Cells were seeded in 96-well plates $\left(3 \times 10^{4}\right.$ cells/well) with or without $0.45 \mu \mathrm{g} / \mathrm{mL}$ anti-dinitrophenyl (DNP) IgE (Sigma Chemical Co, St. Louis, MO, USA). After overnight incubation, the sensitized or unsensitized cells were washed twice with serum-free RPMI1640 medium, and then were treated for 4 or $24 \mathrm{~h}$ with the indicated concentration of GlcN$\mathrm{HCl}$, GlcNAc, chitin oligomer or chitosan oligomer dissolved in serum-free RPMI-1640 medium. After washing twice with Tyrode's buffer $(1.17 \mathrm{mM} \mathrm{NaCl}, 5.4 \mathrm{mM} \mathrm{KCl}, 2.0 \mathrm{mM}$ $\mathrm{CaCl}_{2}, 1.0 \mathrm{mM} \mathrm{MgCl}$, $5.6 \mathrm{mM}$ glucose, $25 \mathrm{mM}$ HEPES, 0.1\% BSA, pH 7.7), the cells were incubated with $120 \mu \mathrm{L} /$ well Tyrode's buffer containing $1 \mu \mathrm{g} / \mathrm{mL}$ DNP-BSA (Molecular Probes, Eugene, OR, USA) for $30 \mathrm{~min}$. The supernatants were collected, and cell lysates were obtained in Tyrode’s buffer containing 0.1\% Triton X-100 (Sigma). Aliquots (50 $\mu \mathrm{L}$ ) of each supernatant and cell lysate were incubated with $50 \mu \mathrm{L} 5 \mathrm{mM}$ p-nitrophenyl- $N$-acetyl- $\beta$ $D$-glucosaminide (Sigma) in $0.1 \mathrm{M}$ citrate buffer $(\mathrm{pH} 4.5)$ at $37^{\circ} \mathrm{C}$ for $1 \mathrm{~h}$. The reaction was terminated by the addition of $0.1 \mathrm{M} \mathrm{NaHCO} / \mathrm{Na}_{2} \mathrm{CO}_{3}(\mathrm{pH} \mathrm{10.0)}$. p-Nitrophenol, the product 24 of the reaction, was detected by optical absorbance at $405 \mathrm{~nm}$. The percentage of $\beta$ 25 hexosaminidase released was calculated as follows, 
$1 \quad \beta$-hexosaminidase release $(\%)=$ supernatant OD value of the stimulated cells / (the cell

2 lysate OD value + supernatant OD value of the stimulated cells).

$4 \quad$ Measurement of cytosolic $\mathrm{Ca}^{2+}$ concentration

5 Cytosolic $\mathrm{Ca}^{2+}$ concentrations were measured using of the fluorescent indicator Fluo6 4/AM (Dojindo Laboratories, Kumamoto, Japan) (Kempuraj et al. 2005; Takahashi et al. 7 1999). RBL-2H3 cells were cultured overnight in 96-well culture plates at $1.5 \times 10^{4}$ 8 cells/well with $0.45 \mu \mathrm{g} / \mathrm{mL}$ anti-DNP IgE. The cells were treated for $4 \mathrm{~h}$ with $1 \mathrm{mg} / \mathrm{mL}$ of 9 each glucosamine-related compound in RPMI-1640 medium. The treated cells were washed 10 twice and loaded with $4 \mu \mathrm{M}$ Fluo-4/AM in Tyrode's buffer at $37^{\circ} \mathrm{C}$ for $1 \mathrm{~h}$. After washing twice with Tyrode's buffer, the cells were stimulated with $1 \mu \mathrm{g} / \mathrm{mL}$ DNP-BSA for 90 sec. Intracellular calcium mobilization was detected at $485 \mathrm{~nm}$ excitation wavelength and $535 \mathrm{~nm}$ emission wavelength with a Wallac 1420 ARVOSX-FL spectrophotometer (Wallac, Waltham, 14 MA, USA).

Western blot analysis

IgE-sensitized cells were treated with $1 \mathrm{mg} / \mathrm{mL} \mathrm{GlcN-HCl}$ or GlcNAc for $4 \mathrm{~h}$. The cells were stimulated by $1 \mu \mathrm{g} / \mathrm{mL}$ DNP-BSA for $5 \mathrm{~min}$ and then cells were lysed by incubation for $30 \mathrm{~min}$ on ice with lysis buffer ( $25 \mathrm{mM}$ Tris buffered saline, $50 \mathrm{mM}$ sodium fluoride, $1 \mathrm{mM}$ sodium orthovanadate and protease inhibitor cocktail (Roche, Basel, Switzerland)) containing 1\% Triton X-100. For immunoprecipitation of Lyn, equal amount of protein (200 $\mu \mathrm{g})$ of cell lysates were incubated with Lyn specific antibodies (Santa Cruz Biotechnology, Inc, Santa Cruz, CA) coupled to protein G-sepharose (Sigma Chemical Co, St. Louis, MO) with slow rotation overnight at $4^{\circ} \mathrm{C}$. Each precipitated protein was separated by SDS-PAGE, and were 
1 blocked with Blocking One-P (Nacarai Tesque, Inc., Kyoto, Japan). Lyn and phosphorylated

2 Lyn were probed with anti-phospho-Lyn antibody (Sigma) and anti-Lyn antibody at 1:1000

3 dilution for 2 h. For detecting ERK1/2 and phospho-ERK1/2, equal protein of each cell

4 lysates (20 $\mu \mathrm{g}$ ) was separated by SDS-PAGE and transferred to PVDF membranes. After

5 blocking, ERK1/2 and phospho-ERK1/2 were probed with anti-ERK1/2 antibody (Cell

6 signaling technology, Inc., Danvers, MA) and anti-phospho-ERK1/2 antibody (Cell signaling

7 technology, Inc) at 1:1000 dilution for 2 h. HRP-anti-rabbit-antibody (R\&D Systems, Inc.,

8 Minneapolis, MN) was used as the secondary antibody at 1:500 dilutions for $1 \mathrm{~h}$. Detection

9 was performed using Chemi-Lumi One L (Nacalai) and image-analyzer LAS-3000

10 (FUJIFILM, Tokyo, Japan).

Quantification of TNF- $\alpha$ and IL-6 mRNAs by real-time RT-PCR

IgE-sensitized cells were treated with the indicated concentration of each glucosaminerelated compound for $4 \mathrm{~h}$ as described above. After washing twice, cells were stimulated with $1 \mu \mathrm{g} / \mathrm{mL}$ DNP-BSA for $30 \mathrm{~min}$ at $37^{\circ} \mathrm{C}$. Cells were washed sufficiently and total RNAs were extracted using the Sepasol reagent (Nacalai Tesque, Inc. Kyoto, Japan) according to the manufacturer's instructions. RNAs were treated with RNase-free DNase (Invitrogen, Carlsbad, CA, USA) to remove contaminating genomic DNA. After inactivating DNase by heating at $65^{\circ} \mathrm{C}$ for $10 \mathrm{~min}$, each RNA was transcribed to cDNA using SuperScript RNase II reverse transcriptase (Invitrogen, Carlsbad, CA, USA) with random hexamers at $25^{\circ} \mathrm{C}$ for 10 min and then at $42^{\circ} \mathrm{C}$ for $50 \mathrm{~min}$. The reactions were stopped by incubation at $70^{\circ} \mathrm{C}$ for 15 min and then $6 \mu \mathrm{L}$ of each mixture, $10 \mu \mathrm{L}$ iQ SYBR Green supermix (Bio-Rad Laboratories,

23 Hercules, CA, USA) and $2 \mu \mathrm{L}$ TNF- $\alpha$, IL-6 or GAPDH gene-specific primers (forward and reverse) were mixed in a final volume of $20 \mu \mathrm{L}$. Primers used for the quantification of each 
1 based on the analyses by melting curves and by agarose gel electrophoresis. Real-time

2 quantitative PCR was performed using a DNA Engine Opticon system (Bio-Rad

3 Laboratories). The thermal cycler parameters were as follows: $3 \mathrm{~min}$ at $95^{\circ} \mathrm{C}$ for one cycle,

4 followed by amplification for 40 cycles with melting for 15 seconds at $95^{\circ} \mathrm{C}$ and with

5 annealing and extension for 30 seconds at $60^{\circ} \mathrm{C}$. Values were normalized using GAPDH as

6 an endogenous internal standard.

Measurement of DNFB-induced mouse ear swelling

Six-week-old female BALB/c mice were purchased from Japan SLC Inc. (Shizuoka, Japan). The animals were housed at $25^{\circ} \mathrm{C}$ with a 12-hour light/dark cycle and were allowed free access to commercial chow (Oriental Yeast Co., LTD., Tokyo, Japan) and tap water.

12 Animal experiments were performed in accordance with the guidelines of Kyoto University for the use and care of laboratory animals.

In vivo anti-allergic activity was tested by the dinitrofluorobenzene (DNFB) -induced contact hypersensitivity reaction (Maeda et al. 2008). The dorsal skin of each mouse was shaved and $100 \mu \mathrm{L}$ 0.5\% DNFB in acetone-soybean oil (4:1) was applied to that area to sensitize the mice. GlcN-HCl or GlcNAc ( 0.1 or $1 \mathrm{mg} / \mathrm{mouse}$ ) was administrated orally once a day for 6 days. One h after the final administration, both right and left ears were challenged with $20 \mu \mathrm{L}$ 0.5\% DNFB in acetone-soybean oil (4:1). The thickness of the right ear was measured with a Dial Thickness Gauge (Mitutoyo Co., Kanagawa, Japan) 0, 6 and 24 h after the DNFB challenge. The degree of ear swelling was expressed as the percentage of the thickness of the ear measured before DNFB challenge. Twenty four hour after DNFB treatment, blood was collected and mice were sacrificed under anesthesia. Left ear was fixed

24 by formalin solution, and each paraffin section was stained by hematoxylin and eosin (HE) to observe morphological changes. The amount of TNF- $\alpha$ in the right ear was measured by 
1 ELISA kit (Thermo Scientific, Yokohama, Japan). Histamine in the plasma and the right ear

2 was measured by HPLC with fluorescent detection (Yoshitake et al. 2003).

3

$4 \quad$ Statistical analysis

Data are reported as means \pm SD. Statistical analyses were performed by paired-t-test or one-way analysis of variance (ANOVA) with Dunnett's test to identify levels of

7 significance between the groups.

8

$9 \quad$ Results

Effect of glucosamine and related compounds on the antigen-induced degranulation of RBL2H3 cells

As an indicator of the degranulation of RBL-2H3 cells, the release of $\beta$-hexosaminidase from the cells was measured. Pre-treatment with $1 \mathrm{mg} / \mathrm{mL}$ GlcN-HCl for $4 \mathrm{~h}$ significantly reduced the release of $\beta$-hexosaminidase from sensitized RBL-2H3 cells stimulated with 1 $\mu \mathrm{g} / \mathrm{mL}$ DNP-BSA for $30 \mathrm{~min}$ (Fig. 1A). The release of $\beta$-hexosaminidase from cells treated with $1 \mathrm{mg} / \mathrm{mL}$ GlcN-HCl for $4 \mathrm{~h}$ was inhibited by approximately 50\% compared to cells treated with antigen alone. Treatment with GlcN-HCl for 24h significantly inhibited the release of $\beta$-hexosaminidase at more than $0.01 \mathrm{mg} / \mathrm{mL}$ (Fig.1B). In contrast, GlcNAc, a chitin oligomer or a chitosan oligomer had no effect on the antigen-induced degranulation of mast cells (Fig. 1A and B). GlcN-HCl, GlcNAc, chitin oligomer and chitosan oligomer had no direct effect on the enzyme activity of $\beta$-hexosaminidase (data not shown).

Effect of glucosamine and related compounds on the expression of proinflammatory cytokines We examined whether glucosamine and related compounds could modulate the expression of proinflammatory cytokines (TNF- $\alpha$ and IL-6) induced by antigen in RBL-2H3 
1 cells because those cytokines from mast cells are involved in late-phase allergy. Both GlcN-

$2 \mathrm{HCl}$ and GlcNAc significantly suppressed the antigen-induced expression of TNF- $\alpha$ and IL-6

3 mRNAs more than $60 \%$ compared with the control treated with antigen alone, while the

4 chitin oligomer and the chitosan oligomer had no significant effect (Fig. 2A and B).

5

6 Effect of glucosamine- $\mathrm{HCl}$ and $\mathrm{N}$-acetylglucosamine on intracellular $\mathrm{Ca}^{2+}$ mobilization and

7 the activation of intracellular signaling molecules

It is well known that elevation of the intracellular $\mathrm{Ca}^{2+}$ concentration triggers the

9 degranulation of mast cells. We evaluated the effects of GlcN-HCl, GlcNAc, chitin oligomer 10 and chitosan oligomer on intracellular $\mathrm{Ca}^{2+}$ mobilization in RBL-2H3 cells. The results were 11 similar to the effects on degranulation as described above. RBL-2H3 cells stimulated with 1 $12 \mu \mathrm{g} / \mathrm{mL}$ DNP-BSA had increased intracellular $\mathrm{Ca}^{2+}$ levels at 90 sec. Pre-treatment with 1 $13 \mathrm{mg} / \mathrm{mL}$ GlcN-HCl for $4 \mathrm{~h}$ significantly suppressed the antigen-induced elevation of 14 intracellular $\mathrm{Ca}^{2+}$ compared to cells treated with antigen alone (Fig. 3A). GlcNAc, chitin 15 oligomer and chitosan oligomer had no effect on the intracellular calcium mobilization. We 16 examined the effect of GlcN-HCl and GlcNAc on the tyrosine phosphorylation of Lyn which 17 is critical for degranulation. The level of phosphorylated Lyn was increased 2-fold by stimulation with DNP-BSA for 5 min. In GlcN-HCl-treated cells, the DNP-BSA-induced tyrosine phosphorylation of Lyn was significantly lower than in control cells (Fig. 3B). On the other hand, the activation of ERK1/2, which leads to the up-regulation of cytokines gene expression, in both GlcN-HCl and GlcNAc treated cells was significantly reduced as compared with that of the control cells (Fig.3C).

Effect of glucosamine-HCl and N-acetylglucosamine on DNFB-induced ear swelling in 
1 To investigate anti-inflammatory activity in vivo, the effect of oral administration of

2 GlcN-HCl or GlcNAc on DNFB-induced mouse ear swelling was evaluated. DNFB-induced

3 ear swelling is a model for contact hypersensitivity and is caused by cytokines and infiltrating

4 neutrophils. We examined the effects of dietary GlcN-HCl and GlcNAc on DNFB-induced

5 immediate $(6 \mathrm{~h})$ and delayed (24 h) hypersensitivity. Oral administration of GlcN-HCl or

6 GlcNAc for 6 days (0.1 and $1 \mathrm{mg} /$ mouse/day) significantly inhibited DNFB-induced ear

7 swelling in mice at both $6 \mathrm{~h}$ and $24 \mathrm{~h}$ after the DNFB challenge (Fig. $4 \mathrm{~A}$ and B).

Swelling of hypodermal tissue and the infiltration of inflammatory cell were observed

9 in the ear section by histochemical analysis of hematoxylin-eosin staining. In the ear of the

mice administrated GlcN-HCl or GlcNAc, the pathological changes induced by DNFB treatment were mitigated (Fig.5A). The content of TNF- $\alpha$ in the ear of the mice administrated of GlcN-HCl and GlcNAc tended to be reduced as compared with control mice. Oral administration of GlcN-HCl and GlcNAc significantly reduced the concentration of histamine in both ear and plasma of DNFB-treated mice (Fig.5C and D).

\section{Discussion}

In the present study, we demonstrated that GlcN-HCl and GlcNAc have different effects on mast cell activation. GlcN-HCl suppresses the degranulation and up-regulation of inflammatory cytokine gene expression in mast cells while GlcNAc inhibits only the cytokine gene expression. Chitin and chitosan, which are oligomers of GlcNAc and GlcN, respectively, did not affect the antigen-induced reaction of mast cells. Oral administration of GlcN-HCl or GlcNAc (0.1 or $1 \mathrm{mg} /$ day) for 6 days suppressed the ear swelling and histamine levels of 23 plasma and ear in DNFB-treated mice. These results strongly suggested that the anti24 inflammatory effects of dietary GlcN-HCl or GlcNAc in vivo are caused by the inhibition of antigen-induced release of chemical mediators and cytokines from mast cells. 
Mast cells are mainly involved in the inflammation of type I allergy due to the secretion

2 of chemical mediators such as histamine, leukotriene and inflammatory cytokines (Kabu et al.

3 2006). It is well understood that antigen-IgE binding initiates intracellular signaling cascades

4 such as the phosphorylation of Lyn kinase which leads to the phosphorylation of mitogen-

5 activated protein kinase (MAPK), the mobilization of intracellular $\mathrm{Ca}^{2+}$ and degranulation

6 (Kabu et al. 2006; Gilfilan and Tkaczyk. 2006). In the present study, we focused on the

7 effects of glucosamine and related compounds on the degranulation of mast cells. GlcN-HCl,

8 but not GlcNAc, significantly inhibited the antigen-induced degranulation, intracellular $\mathrm{Ca}^{2+}$

9 influx, and the phosphorylation of Lyn in mast cells. The antigen-induced intracellular signaling in mast cells involves the phosphorylation of mitogen-activated protein kinase (MAPK) followed by the activation of nuclear factor-kappa B (NF-kB). Activated NF-kB upregulates TNF- $\alpha$ and IL-6 expression. Proinflammatory cytokines are secreted from degranulated mast cells and induce the infiltration of leukocytes and macrophages to inflamed sites. Activated leukocytes and macrophages release inflammatory cytokines and induce cellular dysfunction (Feldmann et al 1996). It has been shown that GlcN and GlcNAc have inhibitory effects on the IL-1-mediated intracellular signaling cascade by reducing the activation of NF-אB in chondrocytes (Gouze et al. 2002; Largo et al. 2003). GlcN suppresses the inflammation induced by the activation of neutrophils and synoviocytes but GlcNAc has no effect (Hua et al. 2002, Hua et al 2007). In the present study, we show that GlcN-HCl inhibits both degranulation and cytokine expression while GlcNAc only suppresses cytokine expression. Our data support that GlcN-HCl inhibits both degranulation and the upregulation of cytokine genes by suppressing the phosphorylation of Lyn and ERK1/2, and that GlcNAc only affects ERK1/2 phosphorylation, a regulator of cytokine genes. 
1 allergen to induce ear inflammatory reactions including the degranulation of mast cells (Kabu

2 et al. 2006). It has been reported that GlcN is rapidly absorbed after oral administration

3 (Persiani et al. 2005; Pashkova et al. 2009). The absorption rate of the intact form of GlcNAc

4 is lower than GlcN and appreciable amounts of GlcNAc would be deacetylated during the

5 intestinal absorption (Liu et al. 2008; Capps et al. 1966; Robinson 1968). In the present study,

6 oral administration of GlcN-HCl or GlcNAc significantly reduced the levels of histamine in

7 plasma and ear in DNFB-treated mice. Histamine is released from activated mast cells in

8 mucosal tissue and connective tissue. Our data strongly suggest that GlcN hydrolysed from

9 GlcNAc after oral administration inhibits DNFB-induced degranulation of mast cells in mice.

Mast cells provide a critical cellular link between soluble factors and synovial eruptions

and can contribute to the pathogenic mechanisms in the synovium that result in arthritis (Lee et al. 2002; Nigrovic and Lee 2007; Eklund 2007). Thus, mast cells play a very important role in the inflammation of arthritis. A recent study revealed that mast cells are involved in cellular dysfunction via activation induced by immunocomplexes (Complement 3a, Complement 5a receptor and low affinity IgG receptor III) (Baumann et al. 2001). This suggests that the immunocomplexes induce the degranulation of mast cells and the migration of neutrophilis by cytokines released from mast cells and finally evoke inflammation in the joint (Lee et al. 2002). GlcN-HCl and GlcNAc would be the potential effective compounds to relieve inflammation caused by the activation of mast cells. On the other hand, there are some reports that suggest glucosamine has no effect for osteoarthritis (MacAlindon et al. 2004; Felson 2008). The conflicts in clinical trials of glucosamine supplements for osteoarthritis might be due to inter-patient variation in the pathogenic mechanism and the pathological process. 


\section{Figure legends}

2 Fig. 1. Effect of glucosamine and related compounds on antigen-induced degranulation of 3 RBL-2H3 cells.

DNP-IgE sensitized cells were incubated with the indicated concentrations of GlcN$\mathrm{HCl}$, GlcNAc, chitin oligomer or chitosan oligomer for $4 \mathrm{~h}$ (A) or $24 \mathrm{~h}$ (B) and were then

6 stimulated with $1 \mu \mathrm{g} / \mathrm{mL}$ DNP-BSA for $30 \mathrm{~min}$. Released $\beta$-hexosaminidase was measured.

7 Values are means $\pm \mathrm{SD}, n=4$. * Significantly different from control, $P<0.05$. Non, non

8 stimulation; Con, stimulation; GlcN, glucosamine-HCl; GlcNAc, N-acetylglucosamine;

9 Chitin, chitin oligomer; Chitosan, chitosan oligomer.

11 Fig. 2. Effect of glucosamine and related compounds on the mRNA expression of proinflammatory cytokines in RBL-2H3 cells.

Sensitized cells were incubated with $1 \mathrm{mg} / \mathrm{mL}$ GlcN-HCl, GlcNAc, chitin oligomer or chitosan oligomer for $4 \mathrm{~h}$ and then cells were stimulated with $1 \mu \mathrm{g} / \mathrm{mL}$ DNP-BSA for $30 \mathrm{~min}$.

The mRNA expression levels of TNF- $\alpha$ (A) and IL-6 (B) were quantified by real-time RTPCR. Data are presented as fold induction relative to the unstimulated cells. Values are means $\pm \mathrm{SD}, n=4$. $*$ Significantly different from control, $P<0.05$. Abbrevations are the same as those given for Fig. 1.

Fig. 3 Effect of glucosamine-HCl and N-acetylglucosamine on DNP-BSA induced intracellular $\mathrm{Ca}^{2+}$ mobilization and activation of intracellular molecules.

(A) Sensitized cells were loaded with $4 \mu \mathrm{M} \mathrm{Ca}^{2+}$ indicator Fluo-4/AM for $1 \mathrm{~h}$ after treatment with $1 \mathrm{mg} / \mathrm{mL}$ glucosamine or related compounds and were stimulated by 10 mg/mL DNP-BSA for 90 sec. The fluorescence of Fluo-4 was then measured. Values are means $\pm \mathrm{SD}, n=6$. * Significantly different from control, $P<0.05$. (B, C) Sensitized cells 
1 were incubated with GlcN-HCl or GlcNAc for $4 \mathrm{~h}$ and stimulated with DNP-BSA for 5 min.

2 Cell lysate was immunoprecipitated with Lyn specific antibody, and then phosphorylation of

3 Lyn was detected by western blot analysis using anti-phospho-Lyn antibody (B).

4 Phosphorylation of ERK1/2 in the cell lysate was detected using anti-phospho-ERK1/2

5 antibody (C). Western blotting was performed independent three experiments. Data were

6 analyzed by the density of bands and represented the intensity of the bands of phosphorylated

7 Lyn/normal Lyn (B) and phosphorylated ERK/normal ERK (C), as a relative value for that of

8 the non-stimulated cells. Values were means $\pm S D, n=3$. * Significantly different from control,

$9 \quad P<0.05$. Statistical analyses were performed by paired-t-test. Abbrevations are the same as

10 those given for Fig. 1.

12 Fig. 4 Effect of glucosamine-HCl and N-acetylglucosamine on DNFB-induced ear swelling in $\mathrm{BALB} / \mathrm{c}$ mice.

DNFB-sensitized mice were administrated orally with GlcN-HCl or GlcNAc (0.1 or 1 $\mathrm{mg}$ ) once a day for 6 days. One hour after the final administration, the mice were challenged on the ears with $20 \mu \mathrm{L} 0.5 \%$ DNFB in acetone-soybean oil (4:1). Thickness of the ear was measured at $6 \mathrm{~h}(\mathrm{~A})$ and at $24 \mathrm{~h}(\mathrm{~B})$ after treatment with DNFB and values are presented as a percentage of the thickness of the ear measured before DNFB challenge. Values are means \pm SD, $n=3$. *Significantly different from control, $P<0.05$. Abbrevations are the same as those given for Fig. 1.

Fig. 5 Effect of glucosamine-HCl and N-acetylglucosamine on DNFB-induced inflammation.

(A) Twenty-four hours after DNFB-challenge, the ear was fixed by formalin solution and its paraffin section was stained by hematoxylin and eosin (HE). Bars indicate $100 \mu \mathrm{m}$.

(B) The contents of TNF- $\alpha$ in the ear were measured by ELISA kit. Values are means \pm SD, 
$1 n=3 . \quad(\mathrm{C}, \mathrm{D})$ Histamine in ear (C) and plasma (D) was determined by HPLC with

2 spectrofluorometer. Values are means $\pm \mathrm{SD}, n=3$. *Significantly different from control, $P<$

$3 \quad$ 0.05. Abbrevations are the same as those given for Fig. 1.

4

5 


\section{References}

2 Baumann U, Chouchakova N, Gewecke B, Köhl J, Carroll MC, Schmidt RE, Gessner JE.

Distinct tissue site-specific requirement of mast cells and complement components C3/C5a receptor in IgG immune complex-induced injury of skin lung. Journal of Immunology 167, 1022-10, 2001.

Capps CJ, Shetlar MR, Bradford HR. Hexosamine metabolism. I. The absorption and metabolism, in vivo, of orally administrated D-glucosamine and N-acetyl-Dglucosamine in the rat. Biochimica et Biophysica Acta 127, 194-204, 1966.

Eklund KK. Mast cells in the pathogenesis of rheumatic diseases and as potential targets for anti-rheumatic therapy. Immunological Reviews 217, 38-52, 2007.

Feldmann M, Brennan MF, Maini NR. Role of cytokines in rheumatoid arthritis. Annual Review of Immunology 14, 397-440, 1996.

Felson DT. Glucosamine sulfate might have no effect on pain or structural changes associated with osteoarthritis. Nature Clinical Practice Rheumatology 4, 518-519, 2008.

Felson DT, McAlindon TE. Glucosamine and chondroitin for osteoarthritis: to recommend or not to recommend? Arthritis Care and Research 13, 179-182, 2000.

Forchhammer L, Thorn M, Met O, Gad M, Weidner MS, Claesson MH. Immunobiological effects of glucosamine in vitro. Scandinavian Journal of Immunology 58, 404-411, 2003.

Georgopapadakou NH, Tkacz JS. The fungal cell wall as a drug target. Trends in Microbiology 3, 98-104, 1995.

Gilfillan AM, Tkaczyk C. Integrated signaling pathways for mast-cell activation. Nature Reviews Immunology 6, 218-230, 2006. 
1 Gouze JN, Bianchi A, Becuwe P, Dauca M, Netter P, Magdalou J, Terlain B, Bordji K. Glucosamine modulates IL-1-induced activation of rat chondrocytes at a receptor level, and by inhibiting the NF-кB pathway. FEBS Letters 510, 166-170, 2002.

Hua J, Sakamoto K, Nagaoka I. Inhibitory actions of glucosamine, a therapeutic agent for osteoarthritis, on the functions of neutrophilis. Journal of Leukocyte Biology 71, 632640, 2002.

Hua J, Sakamoto T, Kikukawa T, Abe C, Kurosawa H, Nagaoka I. Evaluation of the suppressive actions of glucosamine on the interleukin-1b-mediated activation of synoviocytes. Inflammation Research 56, 432-438, 2007.

Kabu K, Yamasaki S, Kamimura D, Ito Y, Hasegawa A, Sato E, Kitamura H, Nishida K, Hirano T. Zinc Is Required for FceRI-Mediated Mast Cell Activation. Journal of Immunology 177, 1296-1305, 2006.

Kempuraj D, Madhappan B, Christodoulou S, Boucher W, Cao J, Paradopoulou N, Cerulo C, Theoharides T. Flavonols inhibit proinflammatory mediator release, intracellular calcium ion levels and protein kinase $\mathrm{C}$ theta phosphorylation in human mast cells. British Journal of Pharmacology 145, 934-944, 2005.

Kim JC, Shin JY, Shin DH, Kim SH, Park SH, Park RD, Park SC, Kim YB, Shin YC. Synergistic anti-inflammatory effects of pinitol and glucosamine in rats. Phytotherapy Research 19, 1048-1051, 2005.

Kuma MNVR, Muzzarelli RAA, Muzzarelli C, Sashiwa H, Domb AJ. Chitosan Chemistry and Pharmaceutical Perspectives. Chemical Reviews 104, 6017-6084, 2004.

Largo R, Alvarez-Soria MA, Diez-Ortego I. Glucosamine inhibits IL-1beta-induced NFkappaB activation in human osteoarthritic chondrocytes. Osteoarthritis Cartilage 11, 290-298, 2003. 
1 Laverty S, Sandy JD, Celeste C, Vanchon P, Marier JF. Synovial fluid levels and serum pharmacokinetics in a large animal model following treatment with oral glucosamine at clinically relevant doses. Arthritis Rheumatism. 52, 181-191, 2005.

Lee DM, Friend DS, Gurish MF, Benoist C, Mathis D, Brenner MB. Mast cells: A cellular link between autoantibodies and inflammatory arthritis. Science 297, 1689-1692, 2002.

Liu Y, Li Z, Liu G, Jia J, Li S, Yu C. Liquid chromatography-tandem mass spectrometry method for determination of N-acetylglucosamine concentration in human plasma. Journal of Chromatography B. 862, 150-154, 2008.

McAlindon T, Formica M, LaValley M, Lehmer M, Kabbara K. Effectiveness of glucosamine for symptoms of knee osteoarthritis. Results from an internet-based randomized double-blind controlled trial: American Journal of Medicine 117, 643-649, 2004.

Maeda A, Beissert S, Schwarz T, Schwarz A. Phenotypic and functional characterization of ultraviolet radiation-induced regulatory $\mathrm{T}$ cells. Journal of Immunology 180, 30653071, 2008.

Meininger CJ, Kelly KA, Li H, Haynes TE, Wu G. Glucosamine inhibits inducible nitric oxide sythesis. Biochemical and Biophysical Research Communications 279, 234-239, 2000.

Nakano N, Nakao A, Uchida T, Shirasaka N, Yoshizumi H, Okura K, Tsuboi R, Ogawa H. Effects of arachidonic acid analogs on FceRI-mediated activation of mast cells. Biochimica et Biophysica Acta. 1738, 19-28, 2005.

Nigrovic PA, Lee DM. Synovial mast cells: role in acute and chronic arthritis: Immunological Reviews 217, 19-37, 2007.

Pashkova E, Pirogov A, Bendryshev A, Ivanaynen E, Shpigun O. Determination of underivatized glucosamine in human plasma by high-performance liquid 
1

2

3

4

chromatography with electrochemical detection: Application to pharmacokinetic study. Journal of Pharmaceutical and Biomedical Analysis in press, 2009.

Persiani S, Roda E, Rovati LC, Locatelli M, Giacovelli G, Roda A. Glucosamine oral bioavailability and plasma pharmacokinetics after increasing doses of crystalline glucosamine sulfate in man. OsteoArthritis Cartilage. 13, 1041-1049, 2005.

Robinson BG. Distribution of isotopic label after the oral administration of free and bound 14C-labelled glucosamine in rats. Biochemical Journal 108, 275-280, 1968.

Shibata Y, Foster LA, Bradfield JF, Myrvik QN. Oral administration of chitin down-regulates serum IgE levels and lung eosinophilia in the allergic mouse. Journal of Immunology 164, 1314-1321, 2000.

Shikhman AR, Kuhn K, Alaaeddine N, Lotz M. N-acetylglucosamine prevent IL-1 $\alpha$ mediated activation of human chondrocytes. Journal of Immunology 166, 5155-5160, 2001.

Takahashi A, Camacho P, Lechleiter JD, Herman B. Measurement of intracellular calcium. American Physiolical Society 79, 1089-1125, 1999.

Yoshitake T, Ichinose F, Yoshida H, Todoroki K, Kehr J, Inoue O, Nohta H, Yamaguchi M. A sensitive and selective determination method of histamine by HPLC with intramolecular excimer-forming derivatization and fluorescence detection. Biomedical Chromatography 17, 509-516, 2003.

Zhang GX, Yu S, Gran B, Rostami A. Glucosamine abrogates the acute phase of experimental autoimmune encephalomyelitis by induction of Th2 response. Journal of Immunology 175, 7202-7208, 2005. 
Fig. 1

A. $4 \mathrm{~h}$

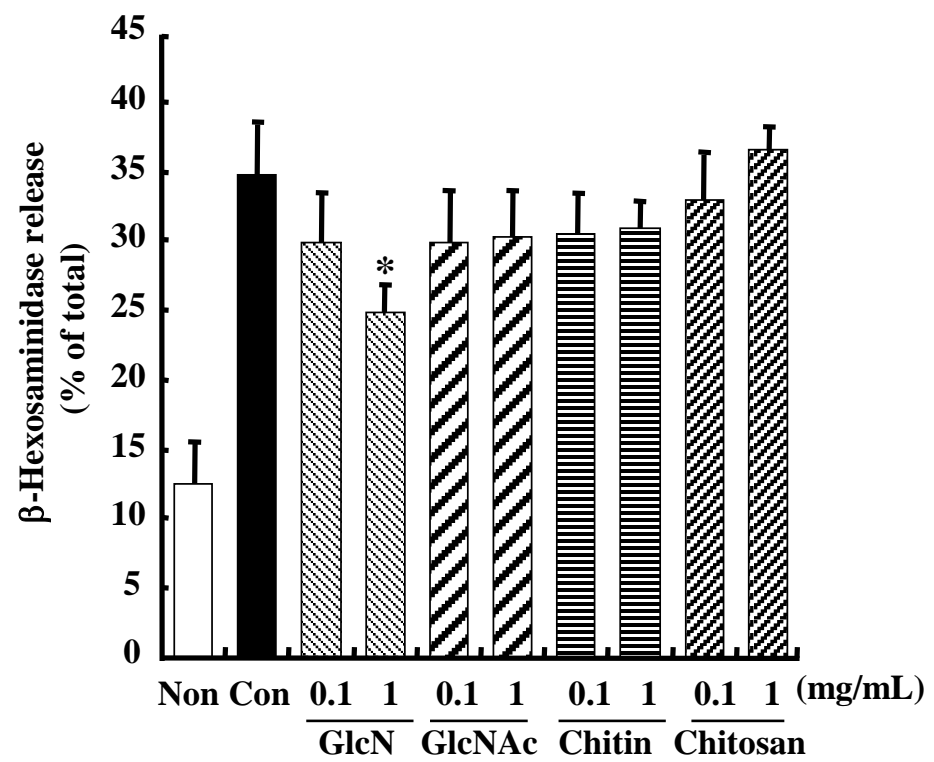

B. $24 \mathrm{~h}$

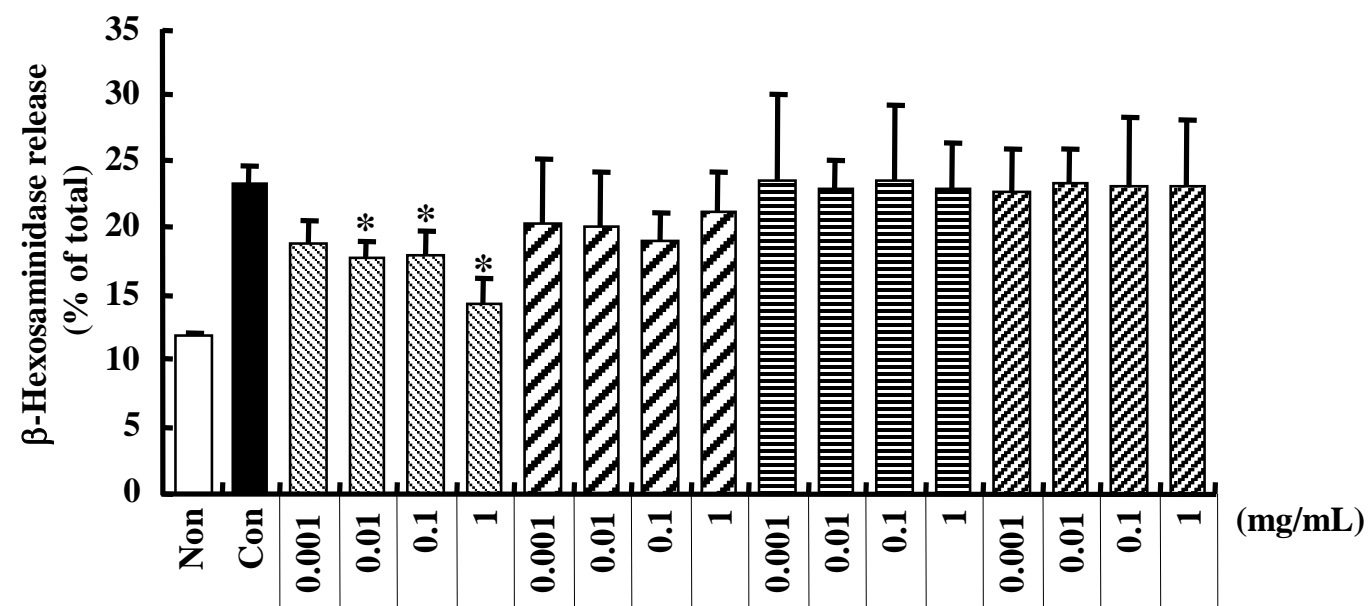

$$
\begin{array}{|l|l|l|l|}
\hline \text { GlcN } & \text { GlcNAc } & \text { Chitin } & \text { Chitosan } \\
\hline
\end{array}
$$


Fig. 2

A. TNF- $\alpha$

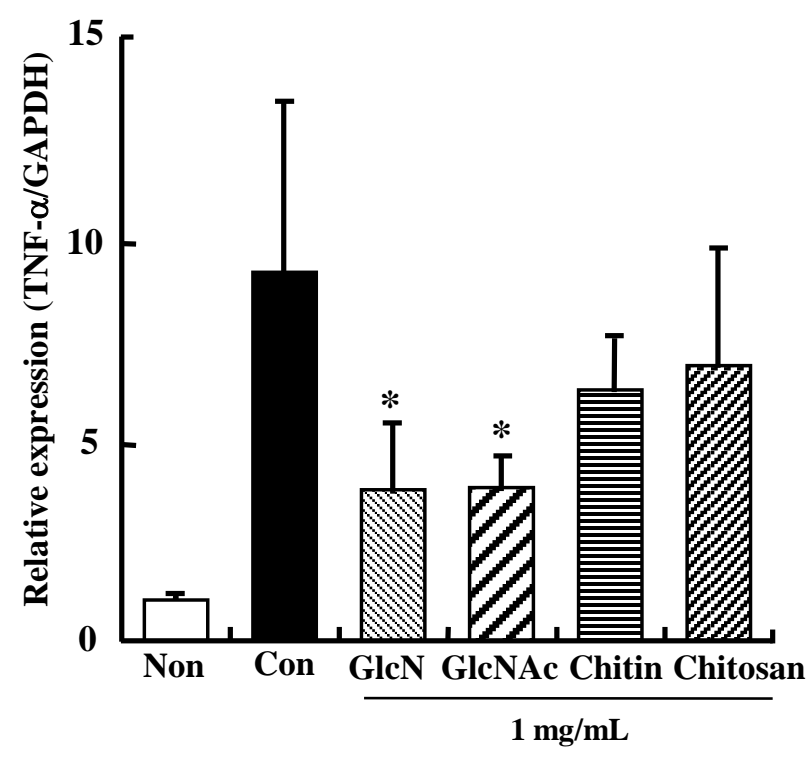

B. IL-6

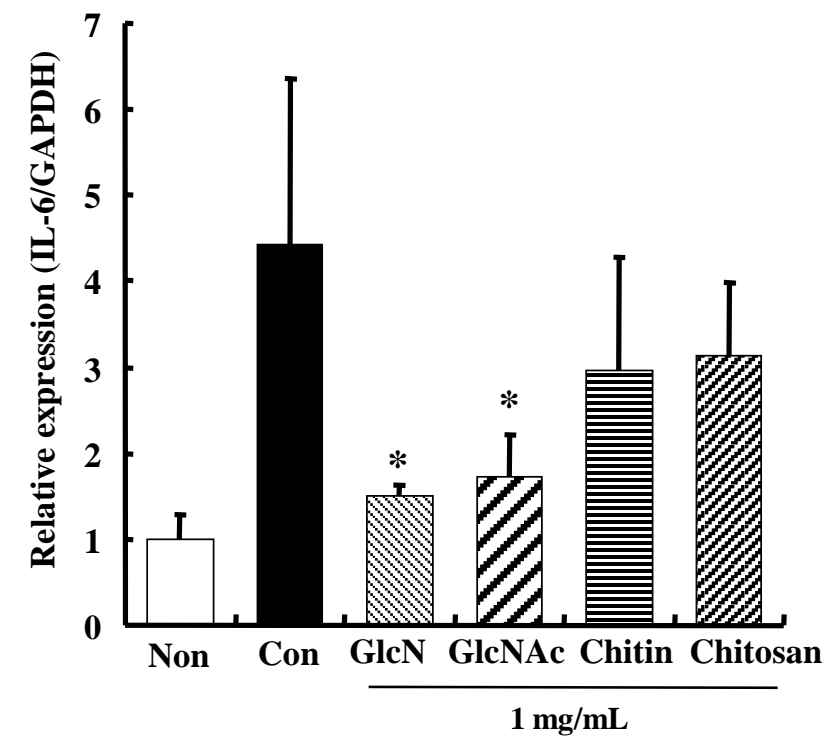


Fig. 3

\section{A. Intracellular $\mathrm{Ca}^{2+}$}

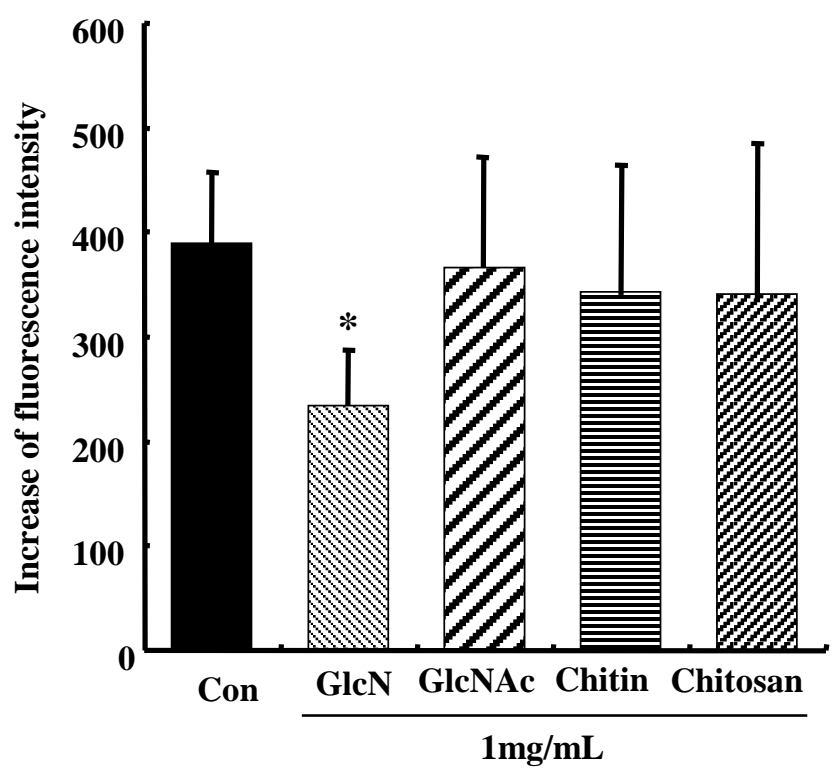

B. Phosphorylation of Lyn
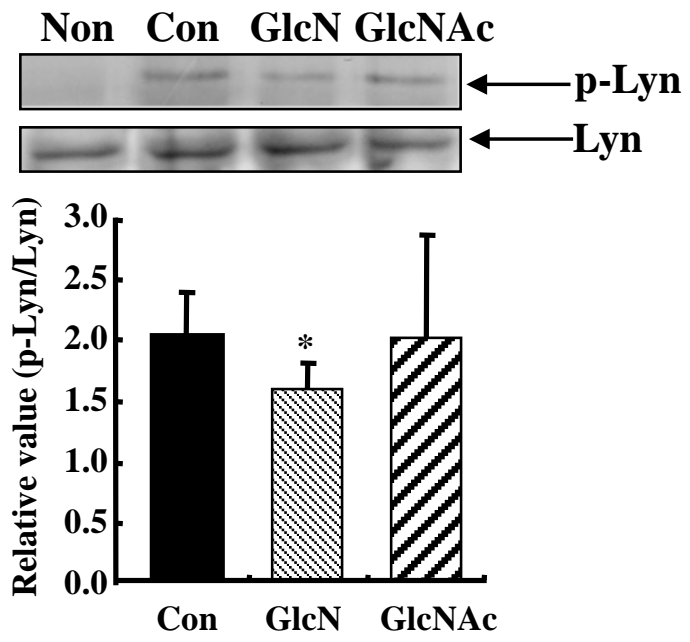

C. Phosphorylation of ERK1/2

Non Con GlcN GIcNAc
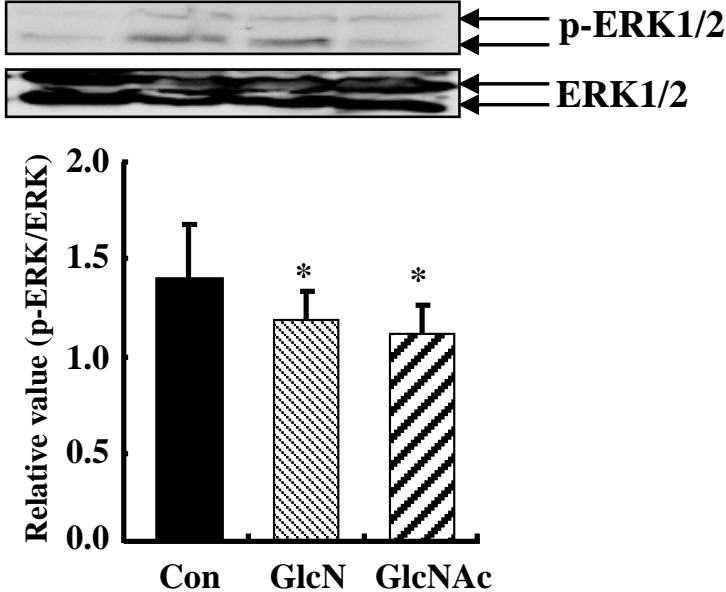
Fig. 4

A. $6 \mathrm{~h}$

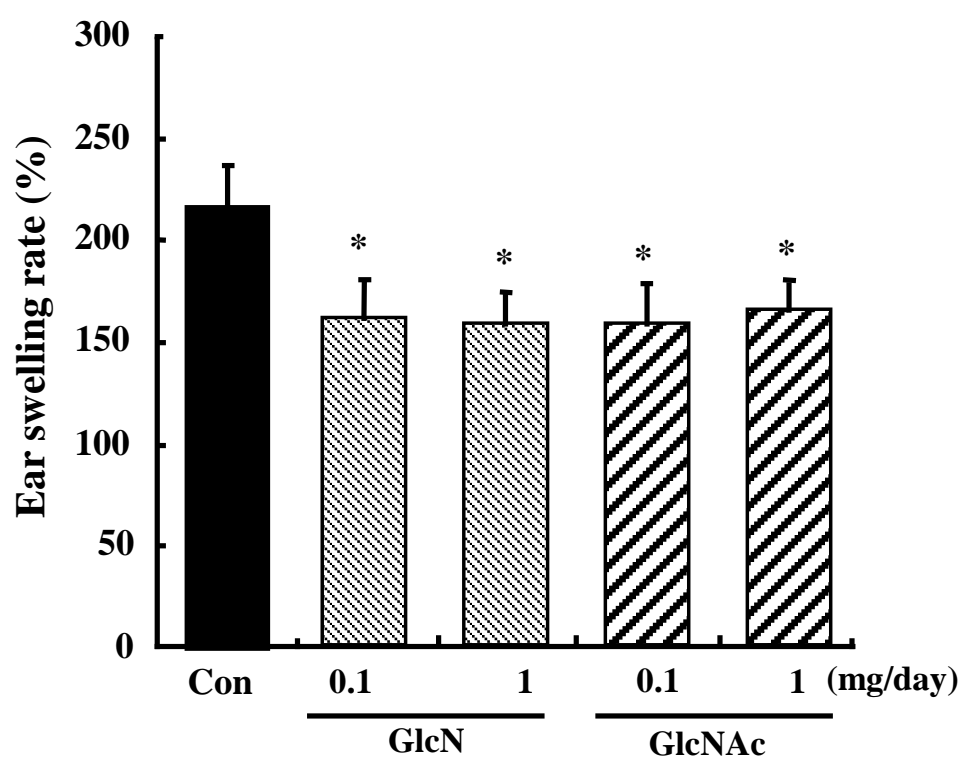

B. $24 \mathrm{~h}$

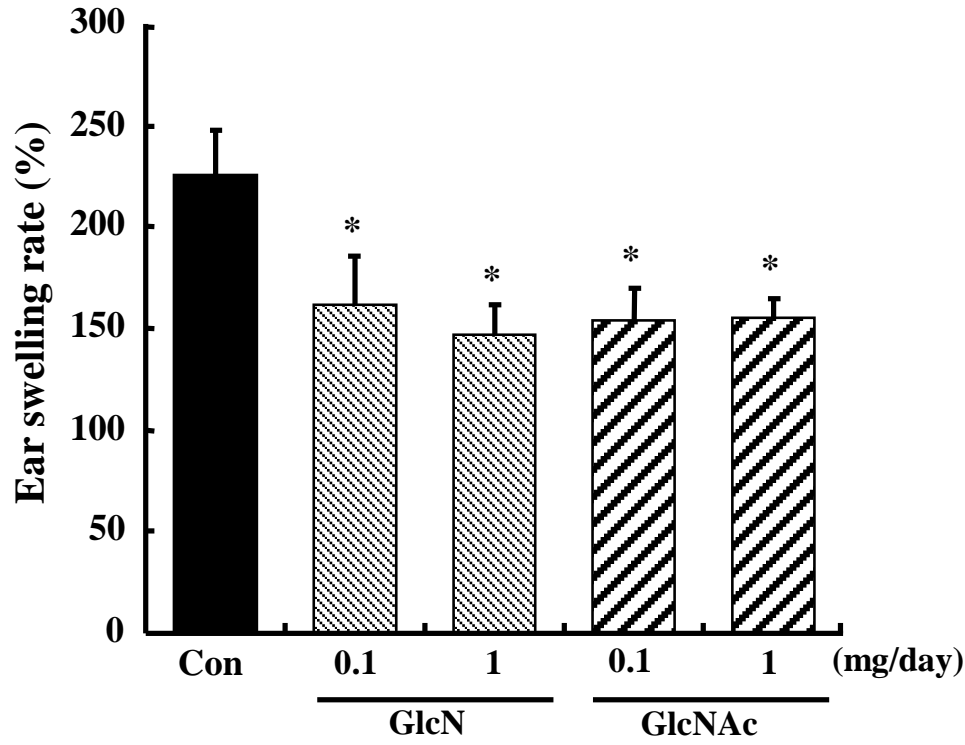


Fig. 5

A.

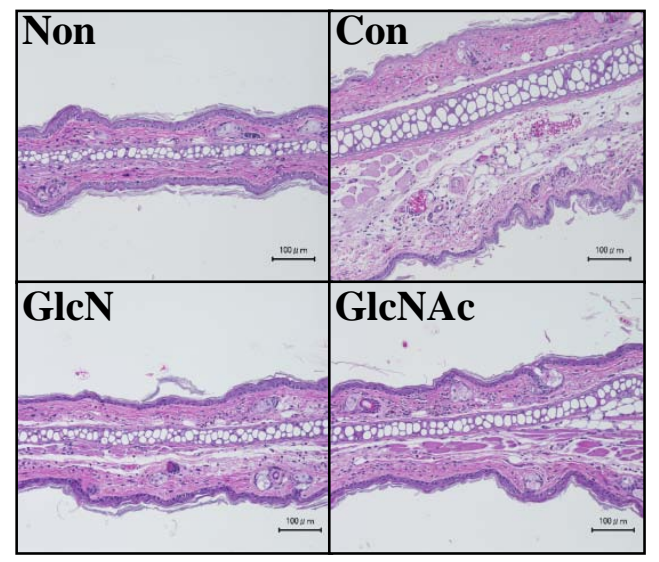

C. Histamine in ear

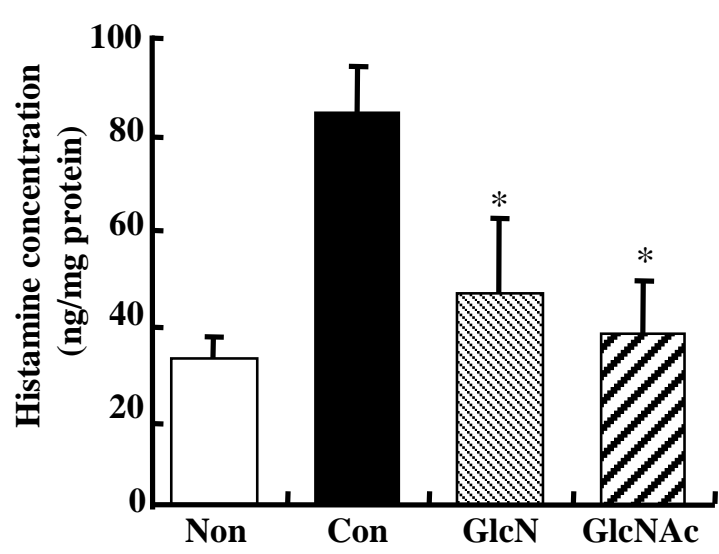

B. TNF- $\alpha$

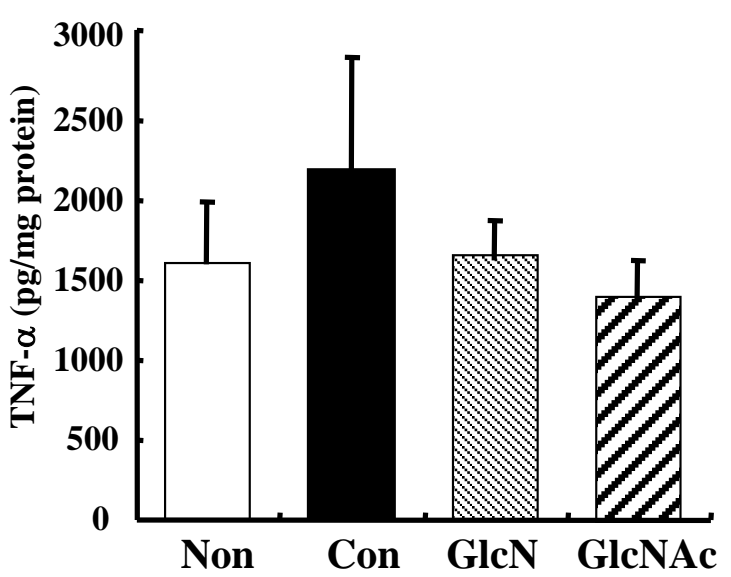

D. Histamine in plasma

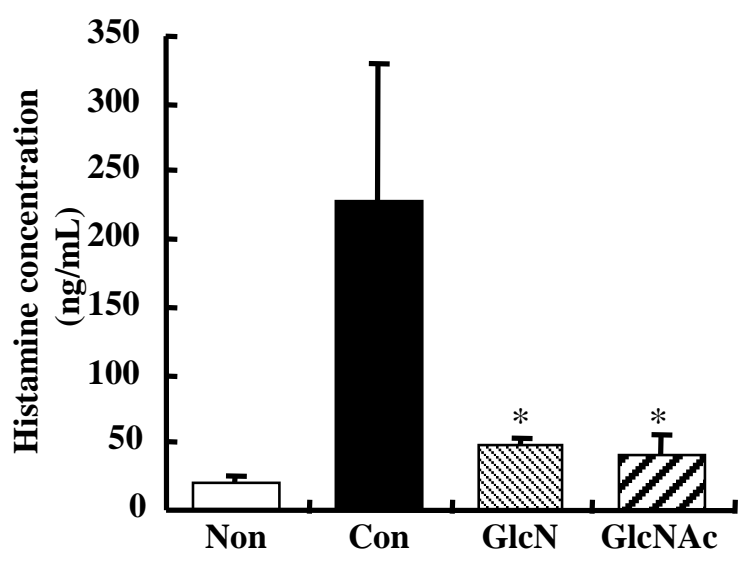

